\title{
REVIEW
}

\section{The renin-angiotensin system in thyroid disorders and its role in cardiovascular and renal manifestations}

\author{
Félix Vargas, Isabel Rodríguez-Gómez, Pablo Vargas-Tendero, Eugenio Jimenez ${ }^{\mathbf{1}}$ and Mercedes Montiel ${ }^{\mathbf{1}}$ \\ Departamento de Fisiología, Facultad de Medicina, Universidad de Granada, E-18012 Granada, Spain \\ ${ }^{1}$ Departamento de Bioquímica y Biología Molecular e Inmunología, Facultad de Medicina, Universidad de Málaga, Boulevard Louis Pasteur 32, \\ 29071 Málaga, Spain \\ (Correspondence should be addressed to F Vargas; Email: fvargas@ugr.es)
}

\begin{abstract}
Thyroid disorders are among the most common endocrine diseases and affect virtually all physiological systems, with an especially marked impact on cardiovascular and renal systems. This review summarizes the effects of thyroid hormones on the renin-angiotensin system (RAS) and the participation of the RAS in the cardiovascular and renal manifestations of thyroid disorders. Thyroid hormones are important regulators of cardiac and renal mass, vascular function, renal sodium handling, and consequently blood pressure (BP). The RAS acts globally to control cardiovascular and renal functions,
\end{abstract}

while RAS components act systemically and locally in individual organs. Various authors have implicated the systemic and local RAS in the mediation of functional and structural changes in cardiovascular and renal tissues due to abnormal thyroid hormone levels. This review analyzes the influence of thyroid hormones on RAS components and discusses the role of the RAS in BP, cardiac mass, vascular function, and renal abnormalities in thyroid disorders.

Journal of Endocrinology (2012) 213, 25-36

\section{Thyroid hormones and the renin-angiotensin system}

Classically, the renin-angiotensin system (RAS) consists of a cascade of reactions in which angiotensinogen, substrate of the RAS, is cleaved by renin released into the circulation to generate the decapeptide angiotensin I (AI). The peptidyldipeptidase angiotensin-converting enzyme (ACE), a membrane-bound metalloprotease primarily present on endothelial cells, converts AI to the octapeptide angiotensin II (AII). AII is the most active known peptide of the RAS and acts on various tissues in the body via selective binding to two major subtypes of G-protein-coupled receptors: AII type 1 $\left(\mathrm{AT}_{1}\right)$ and type $2\left(\mathrm{AT}_{2}\right)$ receptors. The role of the RAS in blood pressure (BP) control is well documented, but it is also involved in the local regulation of numerous functions and can be influenced by different stimuli and hormones, including thyroid hormones.

The RAS is more complex than originally thought, because it operates not only as a circulating endocrine system but also as a local tissue system (Dzau \& Herrmann 1982) that has been identified in most organs and tissues studied (e.g. heart, blood vessels, kidney, adrenal gland, pancreas, CNS, reproductive system, and fatty tissues). It plays an important role in the function of these organs and is involved in cell growth, angiogenesis, proliferation, among others. The local RAS appears to be regulated independently from the circulating system in a specific manner according to the cell type and extracellular stimulus, although it can interact with and complement the circulating system. An intracellular RAS was recently reported, characterized by the presence of a complete functionally active RAS within the cell that can synthesize AII in an independent manner (Kumar et al. 2007). Hence, the RAS is a paracrine and intracrine system as well as an endocrine system (Fyhrquist \& Saijonmaa 2008). Recognition of the important role of intracellular RAS in the cardiovascular system has grown over the past few decades, with observations that the heart, vascular smooth muscle cells (VSMCs), and fibroblasts can intracellularly generate the vasoactive peptide AII.

Thyroid hormones play an important role in BP control but can exert many other effects on the cardiovascular system, and both hypo- and hyperthyroidism can cause cardiovascular dysfunction (Klein \& Ojamaa 1995, 2001, Vargas et al. 2006, Ichiki 2010). Thyroid hormones are known to increase the response of tissues to the action of the sympathetic system, and this may be a mechanism by which they regulate BP. However, thyroid hormones can also activate the RAS 
without involving the sympathetic nervous system (Kobori et al. 2001).

Numerous studies have been performed to characterize the physiological role of thyroid hormones in controlling the synthesis and secretion of RAS components (Jiménez et al. 1982, Montiel et al. 1987, Carneiro-Ramos et al. 2006, Diniz et al. 2009). Several in vivo and in vitro studies have reported that thyroid hormones might modulate the RAS and have evidenced a relationship between the thyroid state and RAS components at both plasma and tissue levels (Kumar et al. 2008, Barreto-Chaves et al. 2010). Thyroid hormones play a major role in the growth and development of various tissues, including the kidney and lung, which are major sites of renin and ACE synthesis; therefore, thyroid hormone deficiency in early developmental stages can have significant effects on RAS components (Chen et al. 2005). In this study, we review the effects of a deficit or excess of thyroid hormones on RAS components (Table 1).

\section{Renin}

Since the discovery of renin 100 years ago, various tissues have been found to express the renin gene, although the main source of circulating renin production is located in juxtaglomerular kidney cells (Kurtz 2011). Renin is an aspartyl protease that cleaves AI decapeptide from the angiotensinogen molecule, and numerous in vivo studies have demonstrated the influence of thyroid hormones on circulating renin. Experimental hyperthyroidism produces an increase in plasma renin activity (PRA) and plasma renin concentration (PRC), while the induction of hypothyroidism in adult rats reduces PRA and PRC (Hauger-Klevene \& Levin 1976, Jiménez et al. 1982). However, different results were obtained when hypothyroidism was induced by surgical thyroidectomy in rats in the first day of life, when an increase in renal renin content (Bouhnik et al. 1981) and PRC (Jiménez et al. 1984) was observed, suggesting the operation of distinct mechanisms according to the age at which the thyroid hormone deficit is produced.

In vitro studies indicated that thyroid hormones influence the synthesis and secretion of renin by juxtaglomerular cells. Ichihara et al. (1998) found that triiodothyronine $\left(\mathrm{T}_{3}\right)$ administration increases renin secretion, renin content, and renin mRNA in rat juxtaglomerular cell cultures. Various authors observed this direct action in cardiac tissue from hyperthyroid rats and reported that thyroid hormones directly stimulate renin mRNA and the promoter activity of the human renin gene via thyroid hormone regulating elementdependent mechanisms (Gilbert et al. 1994, Kobori et al. 1997a,b, 2001). These actions of thyroid hormones on renin secretion and renin mRNA are direct and not mediated by changes in sympathetic nervous system activity (Kobori et al. 1997a,b). However, the above studies do not rule out the possibility that RAS activity modifications in thyroid

Table 1 Plasma and local renin-angiotensin compounds in thyroid hormone excess or deficit

\begin{tabular}{|c|c|c|}
\hline Compound & Hyperthyroidism & Hypothyroidism \\
\hline \multicolumn{3}{|l|}{ Plasma } \\
\hline Angiotensinogen & $\begin{array}{l}\uparrow \text { (Dzau \& Herrmann 1982, Marchant et al. 1993); } \\
\quad \downarrow \text { (Jiménez et al. 1982) }\end{array}$ & $\begin{array}{l}\downarrow \text { (Bouhnik et al. 1981, Jiménez et al. 1982, } \\
\quad \text { Katz 2003) }\end{array}$ \\
\hline Renin & $\begin{array}{l}\uparrow \text { (Hauger-Klevene \& Levin 1976, Jiménez et al. } \\
\text { 1982, Santos \& Ferreira 2007) }\end{array}$ & $\begin{array}{l}\uparrow \text { (Jiménez et al. 1984); } \downarrow \text { (Hauger-Klevene \& } \\
\quad \text { Levin 1976, Jiménez et al. 1982) }\end{array}$ \\
\hline Angiotensin-converting enzyme & $\uparrow$ (Phillips et al. 1993) & $\downarrow$ (Montiel et al. 1987, Jiménez et al. 1990) \\
\hline Angiotensin II & $\begin{array}{l}\uparrow \text { (Marchant et al. 1993, Garcia del Río et al. } \\
\text { 1997, Kobori et al. 1997a,b) }\end{array}$ & $\downarrow$ (Marchant et al. 1993, Kobori et al. 1997a,b) \\
\hline New RAS components & - & - \\
\hline \multicolumn{3}{|l|}{ Heart } \\
\hline Renin & $\uparrow($ Kobori et al. 1997a,b) & - \\
\hline Angiotensin II & $\uparrow$ (Kobori et al. 1997a,b, 1999, Diniz et al. 2007) & $=($ Carneiro-Ramos et al. 2007) \\
\hline $\mathrm{AT}_{1} \mathrm{R}$ & $\begin{array}{l}\rightarrow \text { (Carneiro-Ramos et al. 2010); } \downarrow \text { (Marchant } \\
\text { et al. 1993) }\end{array}$ & $\begin{aligned}= & \text { (Marchant et al. 1993); } \uparrow \text { (Carneiro-Ramos } \\
& \text { et al. 2007) }\end{aligned}$ \\
\hline $\mathrm{AT}_{2} \mathrm{R}$ & $\begin{array}{l}\uparrow \text { (Marchant et al. 1993, Carneiro-Ramos } \\
\text { et al. 2010) }\end{array}$ & $\begin{array}{l}\uparrow \text { (Marchant et al. 1993, Carneiro-Ramos } \\
\text { et al. 2007) }\end{array}$ \\
\hline \multicolumn{3}{|c|}{ 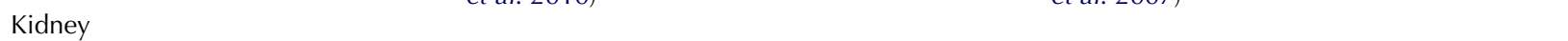 } \\
\hline Renin & $\begin{array}{l}\uparrow \text { (Bouhnik et al. 1981, Kobori et al. 1997a,b, } \\
\text { Klein \& Ojamaa 2001) }\end{array}$ & $\downarrow$ (Kobori et al. 1997a,b) \\
\hline Angiotensin II & $\uparrow($ Klein \& Ojamaa 2001) & - \\
\hline $\mathrm{AT}_{1} \mathrm{R}$ & - & $\downarrow$ (Chen et al. 2005) \\
\hline $\mathrm{AT}_{2} \mathrm{R}$ & - & $\uparrow($ Chen et al. 2005) \\
\hline \multicolumn{3}{|l|}{ Vessels } \\
\hline Renin & - & - \\
\hline Angiotensin II & - & - \\
\hline $\mathrm{AT}_{1} \mathrm{R}$ & $\downarrow$ (Fukuyama et al. 2003) & - \\
\hline $\mathrm{AT}_{2} \mathrm{R}$ & $\uparrow$ (Barreto-Chaves et al. 2010) & - \\
\hline
\end{tabular}

F, Forward; R, reverse. 
disorders in vivo may be in part mediated by changes in $\beta$-adrenergic activity. In fact, an increased number of $\beta$-adrenergic receptors were found in the renal cortex in experimental hyperthyroidism (Haro et al. 1992), and PRA is enhanced by $\beta$-adrenergic stimulation (Churchill et al. 1983) and reduced by $\beta$-adrenergic inhibition (Atlas et al. 1977).

\section{Angiotensinogen}

Thyroid hormones play an important role in angiotensinogen synthesis and consumption. The stage of life at which there is a deficit in thyroid hormone influences the synthesis and release of angiotensinogen in this situation, as is the case for other RAS components.

Plasma angiotensinogen levels in adult rats were not altered by propylthiouracil-induced hypothyroidism (Jiménez et al. 1982), but reduced levels were observed in thyroidectomized animals during early stages of development (Bouhnik et al. 1981, Jiménez et al. 1982, Marchant et al. 1993). The decrease in plasma levels in thyroidectomized rats is partially restored by thyroid hormone treatment (Dzau \& Herrmann 1982) and may reflect a reduced synthesis in the liver, given that the liver content and release of angiotensinogen are both lower in thyroidectomized animals (Clauser et al. 1983, Jiménez et al. 1984). However, contradictory results were reported for plasma angiotensinogen concentrations in adult hyperthyroid rats (Dzau \& Herrmann 1982, Jiménez et al. 1982, Marchant et al. 1993), and no significant changes were observed in hyperthyroid dogs (Sernia et al. 1993). Discrepancies among studies may be due to the different durations and dosages of the thyroid hormone treatments used to induce hyperthyroidism. Furthermore, changes in plasma angiotensinogen concentrations reflect the balance between its synthesis in the liver and its consumption by PRA. Ruiz et al. (1987) found an increase in angiotensinogen synthesis and release in primary cultures of hepatocytes after $T_{3}$ and thyroxine $\left(T_{4}\right)$ administration; therefore, the decrease reported by Jiménez et al. (1982) in hyperthyroid rat plasma may be attributable to the increased angiotensin consumption by circulating renin in these animals.

Although the angiotensinogen molecule is primarily synthesized and released in the liver, angiotensinogen mRNA has been found in various tissues, including the brain and kidneys, while thyroid hormones have been shown to induce angiotensinogen gene expression at the transcriptional level (Chan et al. 1992, Hong-Brown \& Deschepper 1992).

\section{Angiotensin-converting enzyme}

ACE is a key enzyme of the RAS and is directly involved in forming AII, the bioactive peptide of this system, by removing the C-terminal histidyl-leucine residue from AI. ACE is mainly located in the pulmonary vascular endothelium but has also been found in kidney, liver, brain, and cardiovascular tissues, among others.
ACE activity is influenced by thyroid dysfunction at both circulating and tissue levels. Reduced serum and liver ACE concentrations were reported in neonatal rats with hypothyroidism induced by maternal administration of the anti-thyroid drug methimazole and in adult rats treated with propylthiouracil. Conversely, hyperthyroid rats and patients showed an increase in serum ACE concentrations that was positively correlated with thyroid hormone levels (Montiel et al. 1987, Reiners et al. 1988, Jiménez et al. 1990).

ACE transcription regulation is tissue-dependent. ACE activity and expression were increased in the kidney of $\mathrm{T}_{3^{-}}$or $\mathrm{T}_{4}$-treated rats (Michel et al. 1994, Carneiro-Ramos et al. 2006) but reduced in the heart and aorta of $T_{4}$-treated rats (Carneiro-Ramos et al. 2006), although some authors reported higher ACE activity in the heart of $\mathrm{T}_{3}$-treated rats (Michel et al. 1994). In another study, thyroid hormones were found to induce ACE synthesis in endothelial cells (Dasarathy et al. 1990).

\section{AII and AII receptors}

AII, the main peptide of the RAS, exerts it action by interacting with two types of receptors, $\mathrm{AT}_{1}$ and $\mathrm{AT}_{2}$. The $\mathrm{AT}_{1}$ receptor is a G-protein-coupled receptor widely expressed in numerous tissues. It mediates most actions of AII (e.g. fluid and electrolyte control and cell growth remodeling and differentiation) and is the main receptor involved in cardiovascular diseases, among many others. The $\mathrm{AT}_{2}$ receptor subtype appears to have contrary effects to those of the $\mathrm{AT}_{1}$ receptor, although this depends on the tissue in which they are expressed.

AII levels largely depend on the systemic or tissue levels of renin and angiotensinogen. An increase or deficit in thyroid hormone changes renin and angiotensinogen levels and consequently affects AII levels. The rise in PRA and plasma angiotensinogen observed in hyperthyroidism is associated with increased plasma AII levels, which are reduced in hypothyroidism (Marchant et al. 1993, Kobori et al. 1997a,b). However, the action of thyroid hormones on angiotensin receptors is tissue-dependent. AII receptors in atrium, thoracic aortic, and liver tissues were increased in experimental hyperthyroidism in dogs (Sernia et al. 1993), similar to the findings by Marchant et al. (1993) in hyperthyroid rats, in which AII receptors were increased in the heart, liver, and kidneys but reduced in the adrenal gland. However, when the latter study characterized the receptors in the heart by pharmacological inhibitors, they found that $\mathrm{AT}_{2}$-subtype density was markedly increased in both hyper- and hypothyroidism, whereas $\mathrm{AT}_{1}$-subtype density was decreased in hyperthyroidism and unchanged in hypothyroidism (Marchant et al. 1993).

In thyroidectomized fetal sheep, $\mathrm{AT}_{1} \mathrm{RNA}$ expression was decreased in the kidneys and lungs, whereas $\mathrm{AT}_{2} \mathrm{mRNA}$ expression was increased in the kidneys (Chen et al. 2005). A decrease in $A T_{1}$ receptors was also observed after $T_{3}$ 
administration to cultures of VSMCs and rat aorta and may result from a downregulation of the $\mathrm{AT}_{1}$ receptor due to the local generation of higher AII values. The mechanism by which thyroid hormones modulate $\mathrm{AT}_{1}$ receptor operates at transcriptional and post-transcriptional levels (Fukuyama et al. 2003).

\section{New RAS components}

The past decade has seen the discovery of several new RAS components. The recently described ACE2-Ang-(1-7)-Mas system is mainly expressed in the kidneys, heart, and blood vessels and can counteract the effects of AII by Mas receptor and $\mathrm{AT}_{1}$ heterodimerization, especially at the cardiovascular level (Santos \& Ferreira 2007). The (pro)renin receptor that binds to and activates renin in tissues was also recently discovered (Vargas et al. 2009) and, although its functional significance has not been fully elucidated, it can amplify local effects of the RAS. Moreover, activation of the intrarenal RAS by the metabolic receptor GPR 91 for succinate, closely associated with oxidative stress, has a hormone-like signaling function in the distal nephron-collecting duct system, which is the major source of (pro)renin in diabetes (Peti-Peterdi 2010) and AII-dependent hypertension (Prieto-Carrasqueo et al. 2009). Thyroid hormones can also be expected to have some regulatory effects on these components, although we were unable to trace reports on this specific issue.

\section{The RAS in low- $T_{3}$ syndrome and subclinical thyroid disorders}

Changes in thyroid function parameters are observed in starvation and fasting, cardiac disease (Kozdag et al. 2005, Pingitore et al. 2005), renal disease (Lim et al. 1980, Zoccali et al. 2005), renal transplantation (Hekmat et al. 2010), ageing (Tognini et al. 2010), and increased saline intake (Cruz et al. 2011), leading to low- $\mathrm{T}_{3}$ syndrome (also known as non-thyroidal illness syndrome or euthyroid sick syndrome). This syndrome is characterized by low circulating $T_{3}$ levels and normal or decreased $T_{4}$ levels and, usually, by normal thyroid stimulating hormone (TSH) levels. It remains controversial whether a reduction in $T_{3}$ during critical illness represents an adaptive change to reduce catabolism. Conversely, the low $\mathrm{T}_{3}$ levels could contribute to the severity of illness (Warner \& Beckett 2010, Economidou et al. 2011). Several factors have been implicated in low- $\mathrm{T}_{3}$ syndrome, including: increased $\mathrm{T}_{3}$ receptor expression, which may be responsible for maintaining euthyroidism in the face of reduced circulating thyroid hormone levels (Williams et al. 1989); reduced enzyme activity of $5^{\prime}$-monodeiodinase, responsible for converting $\mathrm{T}_{4}$ to $\mathrm{T}_{3}$ in peripheral tissues (Mebis \& Van den Berghe 2011); reduced plasma selenium concentration, a shared cofactor with antioxidant enzymes and deiodinases (Van Lente \& Daher 1992); increased cytokine levels
(Hermus et al. 1992, Boelen et al. 1995); and increased levels of Triac $\left(\mathrm{T}_{3}\right.$ analog) and/or Tetrac $\left(\mathrm{T}_{4}\right.$ analog), which may feedback to the pituitary/hypothalamus region and cause a secondary hypothyroidism (Carlin \& Carlin 1993). Low- $\mathrm{T}_{3}$ syndrome is also a strong prognostic predictor of death in patients with heart disease, giving additional information to the conventional clinical and functional cardiac parameters (Iervasi et al. 2003, Kozdag et al. 2005, Pingitore et al. 2005).

The few studies to address RAS activity in low- $\mathrm{T}_{3}$ syndrome were performed under different conditions and yielded contradictory results. Thus, Gottardis et al. (1992) performed a prospective study on the effect of decreased serum $\mathrm{T}_{3}$ levels on atrial natriuretic peptide, aldosterone, AII, renin, and antidiuretic hormone in organ donors before organ harvesting. They observed secondary $\mathrm{T}_{3}$ hypothyroidism and a marked PRA elevation in these patients but no significant change in ADH or aldosterone, indicating a dissociation of the renin-angiotensin-aldosterone mechanism in brain-dead patients. Emdin et al. (2004) also reported that PRA and aldosterone levels were significantly higher in heart failure patients than in healthy subjects and showed a significant linear increase from controls through to patients with severe heart failure, while $T_{3}$ and $\mathrm{FT}_{3}$ levels were significantly decreased in heart failure patients. However, subsequent studies reported normal PRA and aldosterone values in heart failure patients (Pingitore et al. 2008, Fontana et al. 2012), and Pingitore et al. (2008) found a significant decrease in plasma aldosterone but no change in PRA after $\mathrm{T}_{3}$ infusion.

Subclinical hypo- and hyperthyroidism are defined as normal serum-free $T_{4}$ and $T_{3}$ levels associated with elevated or subnormal serum TSH levels, respectively, with scant symptoms or signs of thyroid dysfunction. Subclinical hypothyroidism is relatively prevalent in the general population, especially among women and the elderly, and both subclinical thyroid dysfunctions are associated with detrimental effects on the cardiovascular system (Romaldini et al. 2004, Duggal et al. 2007, Donangelo \& Braunstein 2011). Subclinical hypothyroidism is characterized by decreased cardiac contractility; increased peripheral vascular resistance; abnormal lipid metabolism; cardiac dysfunction; diastolic hypertension, which confers an elevated risk of atherosclerosis; and ischemic heart disease (Mikhail et al. 2008, Ochs et al. 2008, Ashizawa et al. 2010, Razvi et al. 2010, Cai et al. 2011). For its part, subclinical hyperthyroidism is associated with atrial fibrillation, increased cardiac contractility and left ventricular mass, and diastolic and systolic dysfunction, and these patients are almost threefold more likely to suffer atrial fibrillation (Romaldini et al. 2004, Duggal et al. 2007, Donangelo \& Braunstein 2011). Only one study has analyzed RAS activity in these subclinical thyroid disorders, finding no differences in PRA or plasma aldosterone between patients with subclinical hypothyroidism and normal individuals (Sahún et al. 2001). Further research is required to develop knowledge on RAS activity in these thyroid conditions. 


\section{Role of the RAS in cardiovascular and renal abnormalities}

\section{Blood pressure}

Abnormalities in BP control are observed in both hypo- and hyperthyroid states in humans and animals (Klein \& Ojamaa 1995, 2001, Larsen et al. 1998). Pathophysiological changes in hyperthyroidism are usually the opposite of those in hypothyroidism. Thus, hyperthyroidism is characterized by a hyperdynamic circulation and elevated BP, whereas hypothyroidism is associated with a reduced cardiac output and reduced BP (Klein \& Ojamaa 1995, 2001, Larsen et al. 1998), and some experimental models of hypertension have been accelerated by hyperthyroidism (Vargas et al. 1988) and prevented or reversed by hypothyroidism (Vargas et al. 1988, Andrade et al. 1992).

The RAS plays an important role in regulating cardiovascular and renal functions (Guyton 1980) and consequently in regulating BP. As reported above, hypothyroidism is associated with low PRA (Hauger-Klevene et al. 1977, Bouhnik et al. 1981), whereas hyperthyroidism is accompanied by RAS hyperactivity (Ganong 1982, Jiménez et al. 1982, Marchant et al. 1993). Hence, PRA and plasma angiotensinogen, AII, and aldosterone levels are directly related to plasma thyroid hormone concentrations (Ganong 1982, Jiménez et al. 1982, Marchant et al. 1993). Acute RAS blockade markedly decreases arterial pressure and improves renal hemodynamics in hypertensive hyperthyroid rats (García-Estañ et al. 1995), and the long-term administration of captopril prevents $\mathrm{T}_{4}$-induced hypertension (García del Río et al. 1997), indicating an important role for the RAS in the elevated BP of hyperthyroidism.

Increased BP in the hyperthyroid state has been considered a model of cardiogenic hypertension (Klein 1990, Klein \& Ojamaa 1995, Larsen et al. 1998), in which the elevated BP is largely maintained by increased cardiac output secondary to elevated stroke volume and higher heart rate. However, hyperthyroid rats treated with captopril showed normal BP with elevated heart rate and probably higher cardiac output (García del Río et al. 1997), indicating the importance of the RAS and that the increased cardiac output is not the main factor responsible for hypertension in hyperthyroidism.

$\mathrm{T}_{4}$ accelerates the course of Goldblatt $2 \mathrm{~K}-1 \mathrm{C}$ hypertension (typical renin-dependent model), while production of a hypothyroid state simultaneously with its experimental induction prevents this hypertension (Vargas et al. 1988). These data suggest that thyroid hormones modulate the pressor effect of the RAS. However, the suppression of thyroid hormone levels does not reverse $2 \mathrm{~K}-1 \mathrm{C}$ hypertension in its established phase (Vargas et al. 1992). The discrepant effects of hypothyroidism in established hypertension have not been explained, although they may involve irreversible morphological changes in the vascular wall (Folkow 1990).

\section{Cardiac mass}

Mechanisms underlying cardiac hypertrophy secondary to elevated thyroid hormone levels include a direct hormonal effect on the heart and indirect effects related to adrenergic nervous system stimulation and left ventricular loading conditions (Klein 1988, 2003, Morgan \& Baker 1991). Besides increasing cardiac work by raising the systolic BP and heart rate, thyroid hormones upregulate the gene expression of atrial natriuretic factor (ANF), a major marker of cardiomyocyte hypertrophy, in isolated cardiomyocytes (Eppenberger-Eberhardt et al. 1997) and regulate the transcription of various genes related to myocyte contractile machinery after binding to nuclear receptors (Brent et al. 1991).

Several authors have described a close relationship between thyroid hormone levels and the RAS in the development of cardiac hypertrophy in hyperthyroidism (Kobori et al. 1997a,b, 1999, Hu et al. 2003, Carneiro-Ramos et al. 2006, 2007, Diniz et al. 2007, 2009). Kobori et al. (1997a,b, 1999) demonstrated that cardiac renin, renin mRNA, and AII levels are all increased in thyroxin-treated rats in a manner independent of the sympathetic nervous system and circulating RAS, and that these increases contribute to the development of cardiac hypertrophy (Kobori et al. 1997a,b). Moreover, thyroxin-induced cardiac hypertrophy is reduced by blockade of the $\mathrm{AT}_{1}$ receptor with losartan (Kobori et al. 1997a,b, 1999, Hu et al. 2003), independently of sympathetic activation (Kobori et al. 1997a,b). However, the ACE inhibitor captopril, which is clinically effective at reducing cardiac hypertrophy in essential arterial hypertension (Dunn et al. 1984), inhibited circulating RAS and reduced BP but failed to prevent cardiac hypertrophy in $\mathrm{T}_{4}$-treated hyperthyroid rats (Bedotto et al. 1989, García del Río et al. 1997). These discrepancies may be explained by differences in pharmacological effects between ACE inhibitors and AII receptor antagonists, given that ACE-independent AII synthesis has been reported in the heart (Urata et al. 1990, Phillips et al. 1993); therefore, chronic administration of an ACE inhibitor may not completely inhibit cardiac AII synthesis. However, positive effects on thyroid-induced cardiac hypertrophy have also been obtained with ACE inhibitors (Hu et al. 2003), while negative effects have been found with losartan (Rodríguez-Gómez et al. 2003). Consistent with the negative outcomes reported with losartan, AII exerts a direct growth effect on neonatal cardiac cells but does not promote growth responses in adult cardiomyocytes (Sadoshima \& Izumo 1993, Wada et al. 1996).

RAS components are known to act locally and under differential regulation (Bader 2002). There is substantial evidence that most of the AII in cardiac tissue derives from the myocardial synthesis of AI rather than from the systemic circulation (Katz 2003). The intracellular synthesis of AII is evidenced by the presence of AII in cardiomyocytes (Dostal et al. 1992) and by the release of AII into the medium in cardiomyocyte cultures (Sadoshima \& Izumo 1993). Besides 
its well-documented hemodynamic impact, circulating and locally generated AII also stimulates cardiomyocyte growth and fibrosis in the adult myocardium and modulates cardiac hypertrophy (Morgan \& Baker 1991, Fischer \& HilfikerKleiner 2007).

Thyroid hormones activate growth in cardiomyocytes in vitro and in vivo (Kuzman et al. 2005, Kenessey \& Ojamaa 2006). The RAS is activated in hyperthyroidism and is probably involved in the development of cardiac hypertrophy, given that AII acts as a myocyte growth factor (Baker \& Aceto 1990, Fischer \& Hilfiker-Kleiner 2007) and the $\mathrm{AT}_{1}$ receptor behaves as a mediator of AII-induced cardiac hypertrophy (Sadoshima \& Izumo 1993). However, Carneiro-Ramos et al. (2010) observed no change in cardiac $\mathrm{AT}_{1}$ receptor expression in hyperthyroidism-induced cardiac hypertrophy. The same study found that $\mathrm{AT}_{2}$ receptor expression is increased in thyroid hormone-induced cardiac hypertrophy and that the $\mathrm{AT}_{2}$ receptor is involved in the development of thyroid hormone-induced cardiac hypertrophy in vivo and in vitro. Although the effects of the $\mathrm{AT}_{2}$ receptor are generally opposite to those of the $\mathrm{AT}_{1}$ receptor, several studies have reported that both receptors are expressed in some tissues (Booz 2004). For instance, $\mathrm{AT}_{1}$ and $\mathrm{AT}_{2}$ receptors share, at least in part, a common signaling pathway in cardiac tissue (Mifune et al. 2000, Ichihara et al. 2001), which may explain the similar effects observed after their stimulation.

Recent studies suggested that thyroid hormone also acts via a non-genomic mechanism by binding to plasma cytoplasmic membrane receptors that are able to activate signaling pathways (Davis et al. 2005). In this context, acute experiments showed that local AI and AII levels and $\mathrm{AT}_{1}$ receptor expression are rapidly increased by $\mathrm{T}_{3}$ treatment, and that $\mathrm{AT}_{1}$ receptor silencing and blockade totally prevents $\mathrm{T}_{3}$-induced cardiomyocyte hypertrophy (Diniz et al. 2009).

Other studies focused on the intracellular transduction mechanisms underlying the rapid effects of $\mathrm{T}_{3}$ on cultured cardiomyocytes. $\mathrm{T}_{3}$ was found to produce a fast increase in phosphoinositide-3-kinase activity with a consequent activation of its downstream effectors, as one of the mechanisms by which thyroid hormone regulates physiological cardiac growth (Kenessey \& Ojamaa 2006). Diniz et al. (2009) also found that PI3K mediates the rapid activation by $\mathrm{T}_{3}$ of the Akt/GSK3-b/mTOR signaling pathway in cardiomyocyte cultures, reporting that PI3K inhibition completely blocks activation of this $T_{3}$-promoted signaling pathway.

AII receptors were also shown to participate in the thyroid hormone induction of cardiac TGF- $\beta 1$ in cardiac hypertrophy (Diniz et al. 2007). Hyperthyroid animals were found to have elevated cardiac AII levels that interact with $\mathrm{AT}_{1}$ and $\mathrm{AT}_{2}$ receptors and increase cardiac TGF- $\beta 1$ mRNA and protein levels, thereby directly or indirectly promoting thyroid hormone-induced cardiac hypertrophy. These authors also reported that cardiac AII levels are not changed in hypothyroid animals.

Another study found that hypothyroid rats have increased cardiac $\mathrm{AT}_{1}$ and $\mathrm{AT}_{2}$ receptors that are not accompanied by
AII changes, confirming these results in primary cultures of cardiomyocytes to rule out possible hemodynamic influences (Carneiro-Ramos et al. 2007). The authors suggested that thyroid hormone deprivation increases $\mathrm{AT}_{1}$ and $\mathrm{AT}_{2}$ receptor expression as a compensatory response. ANF expression, the index of cardiac hypertrophy, was lower in hypothyroid rats than in control animals.

\section{Vascular function}

$\mathrm{T}_{3}$ produces arterial relaxation and reduces systemic vascular resistance, resulting in an increased cardiac output (Vargas et al. 2006). Vascular RAS may participate, at least in part, in the vascular effects of thyroid hormones. Fukuyama et al. (2003) demonstrated that $T_{3}$ downregulates $A_{1}$ receptor mRNA expression at both transcriptional and post-transcriptional levels in cultured VSMCs and rat aorta. The binding assay showed a decrease in $\mathrm{AT}_{1}$ receptor density with no alteration of the affinity to AII. Downregulation of the $\mathrm{AT}_{1}$ receptor attenuates the biological function of AII, reducing the AII-induced $\left[\mathrm{Ca}^{2+}\right]_{\mathrm{i}}$ response. The $\mathrm{AT}_{1}$ receptor is downregulated after several hours of $\mathrm{T}_{3}$-stimulation, indicating that the suppression is a genomic effect of $\mathrm{T}_{3}$. Because a 10 min incubation with $\mathrm{T}_{3}$ does not affect the calcium response, it is unlikely that $\mathrm{T}_{3}$ directly inhibits calcium response to AII. Therefore, genomic effects of $T_{3}$ in downregulating the $\mathrm{AT}_{1}$ receptor may be involved in reducing vascular resistance in the hyperthyroid state. It is possible that $\mathrm{T}_{3}$ may indirectly inhibit vascular $\mathrm{AT}_{1}$ receptor effects via nitric oxide $(\mathrm{NO})$ production (Rodríguez-Gómez et al. 2003) in addition to directly downregulating the $\mathrm{AT}_{1}$ receptor. However, $\mathrm{NO}$ would not participate in modulating $\mathrm{AT}_{1}$ expression after $\mathrm{T}_{3}$ administration, because L-NAME, an inhibitor of $\mathrm{NO}$ synthase, has no effect on $\mathrm{T}_{3}$-induced $\mathrm{AT}_{1}$ receptor downregulation in VSMCs (Fukuyama et al. 2003). Moreover, Barreto-Chaves et al. (2010) showed that $\mathrm{T}_{3}$ upregulates the $\mathrm{AT}_{2}$ receptor in the aorta of hyperthyroid rats and in VSMC cultures treated with pharmacological doses, suggesting that enhanced $\mathrm{AT}_{2}$ receptor expression may also participate in the vasodilation observed in hyperthyroidism.

The systemic response to AII in hyper- and hypothyroid rats was found to be similar to that in controls (Vargas et al. 1991). Vascular reactivity to AII in hindquarter preparations from hypothyroid rats is elevated or normal according to the statistical analysis used (Koehn et al. 1967). However, the systemic response to AII (and to norepinephrine and vasopressin) is markedly reduced in low-renal mass hypertensive rats treated with methimazole, which prevents and reverses the hypertension (Andrade et al. 1992).

The renal vascular response to AII is normal in the isolated perfused kidneys from hypothyroid rats and is not influenced by the blocking of endothelial relaxing factors or by endothelium removal (Moreno et al. 2003). AII has been reported to stimulate NO production in numerous preparations (Millat et al. 1999). The NO inhibitor L-NAME enhances the dose-response curve to AII in control kidneys, 
indicating that NO counteracts the pressor effect of AII in the isolated perfused rat kidney. However, the AII dose-response curve is not modified by L-NAME in hypothyroid preparations, suggesting a reduction of AII-induced $\mathrm{NO}$ release in the hypothyroid kidney. This finding is consistent with observations that hypothyroid kidneys are less responsive to acetylcholine (Vargas et al. 1995), an endotheliumdependent vasodilator that triggers the release of $\mathrm{NO}$ (Furchgott \& Vanhoutte 1989). The normal response to AII in hypothyroid kidneys may also be attributable to a decrease in counter-regulation by $\mathrm{NO}$, as indicated by the reduced response to sodium nitroprusside (Ignarro et al. 1981). However, additional studies are required to determine the cause of this abnormal AII-NO interaction in the vasculature of the hypothyroid kidney.

Vascular reactivity to vasoconstrictors is modulated by $\mathrm{K}^{+}$channels. Thus, $\mathrm{K}^{+}$channel openers inhibit AIIinduced vasoconstriction (McLeod \& Piper 1992), while tetraethylammonium (TEA), a $\mathrm{K}^{+}$channel blocker, induces a dose-dependent increase in vascular sensitivity to AII (Sabineau \& Marthan 1993). TEA administration does not significantly modify the pressor response to AII in hypothyroid rat kidneys (Moreno et al. 2003), possibly because of a lower generation of endothelium-derived hyperpolarization factor in response to vasoconstrictors or, alternatively, a larger number of closed $\mathrm{K}^{+}$channels in compensation for the defective contractile system in the vascular smooth muscle of hypothyroid rats (Sabio et al. 1994). To date, only this last study has investigated the action of hypothyroidism on vascular $\mathrm{K}^{+}$channels, and further research is warranted to elucidate the mechanism responsible for these effects.

Various authors have demonstrated that AII plays a critical role in atherosclerotic vascular disease (Strawn et al. 2000, Lonn et al. 2001), and several reports have examined the relationship between atherosclerosis and thyroid function (Barth et al. 1987, Lev-Ran 1994, Ichiki 2010). For example, a study on the relationship between atherosclerosis and thyroid function in patients with stable angina showed an exacerbated progression of coronary atherosclerosis in patients with lower serum $\mathrm{T}_{3}$ levels (Barth et al. 1987). These findings suggest that thyroid hormones may be protective against atherosclerosis and that the $\mathrm{T}_{3}$-induced downregulation of the $\mathrm{AT}_{1}$ receptor reported above (Fukuyama et al. 2003) may participate in this effect.

\section{Renal hypertrophy}

Thyroid disorders produce morphological and functional changes in the mammalian kidney (Bradley et al. 1974). The kidney-to-body weight ratio is decreased by hypothyroidism and increased by hyperthyroidism (Stephan et al. 1982, García del Río et al. 1997, Vargas et al. 2006), while hypothyroidism impairs renal compensatory hypertrophy in rats (Stephan et al. 1982, Andrade et al. 1992). Bradley et al. (1974) reported that $\mathrm{T}_{4}$-induced renal hypertrophy in vivo is associated with a rise in the mitotic index, and Stephan et al. (1982) found an increase in DNA content. The mechanism is not fully understood, but participation of the RAS has been proposed, because AII is known to have potent cell proliferation effects in several tissues in vitro (Gill et al. 1977) and in vivo (Casellas et al. 1997). Kobori et al. (1998) observed that $T_{4}$ produces renal hypertrophy in rats, with an increase in renal renin mRNA expression and in renal renin and AII levels. They also reported that thyroid hormone-induced renal hypertrophy is reduced by losartan but not by nicardipine, with a decrease in renal AII levels, suggesting a possible role for intrarenal RAS in the renal hypertrophy of hyperthyroidism. However, renal hypertrophy in hyperthyroid rats is not modified by chronic captopril (García del Río et al. 1997) or losartan (Rodríguez-Gómez et al. 2003) treatment. The reasons for these discrepancies are not clear.

\section{Renal sodium handling}

Thyroid disorders have a major impact on renal function and on salt and water metabolism. Experimental hypothyroidism increases diuresis and natriuresis under normal conditions and after various stresses, whereas there is a tendency to retain sodium in hyperthyroidism (Vargas et al. 2006). A shift in the acute pressure diuresis and natriuresis (PDN) response toward higher pressures was observed in hypertensive hyperthyroid rats, attributable to a lower filtered sodium load and higher tubular sodium resorption (Vargas et al. 1994). Because of these changes in the PDN relationship, the BP of hyperthyroid rats must rise to achieve the same sodium excretion rate as in a normal animal. The RAS was found to participate in this phenomenon, given that AII inhibition by captopril significantly improves (without normalizing) the PDN response and renal hemodynamics in hyperthyroid rats but not in controls (García-Estañ et al. 1995). AII blockade with losartan also significantly improves renal hemodynamics and excretion in hyperthyroid rats (García-Estañ et al. 1995). These results indicate that an increased intrarenal activity of the RAS is partly responsible for the blunted renal PDN mechanism of hyperthyroid rats and consequently for their elevated arterial pressure.

\section{Renal injury and proteinuria}

Selective thyroidectomy prevents the deterioration of chronic renal failure in remnant rat kidney (Alfrey 1986) by reducing transcapillary hydraulic pressure (Conger et al. 1989). It has been proposed that these protective effects are mediated by inhibition of the intrarenal RAS, given that thyroid hormones activate the intrarenal RAS and increase renal AII, which exerts cell proliferation effects in the kidney. Therefore, thyroidectomy probably inhibits this effect, with a consequent reduction in transcapillary hydraulic pressure.

Several studies have reported increased proteinuria in hyperthyroid rats, consistent with the presence of proteinuria in patients with Graves' disease (Weetman et al. 1985). This disorder appears to be unrelated to RAS activity 


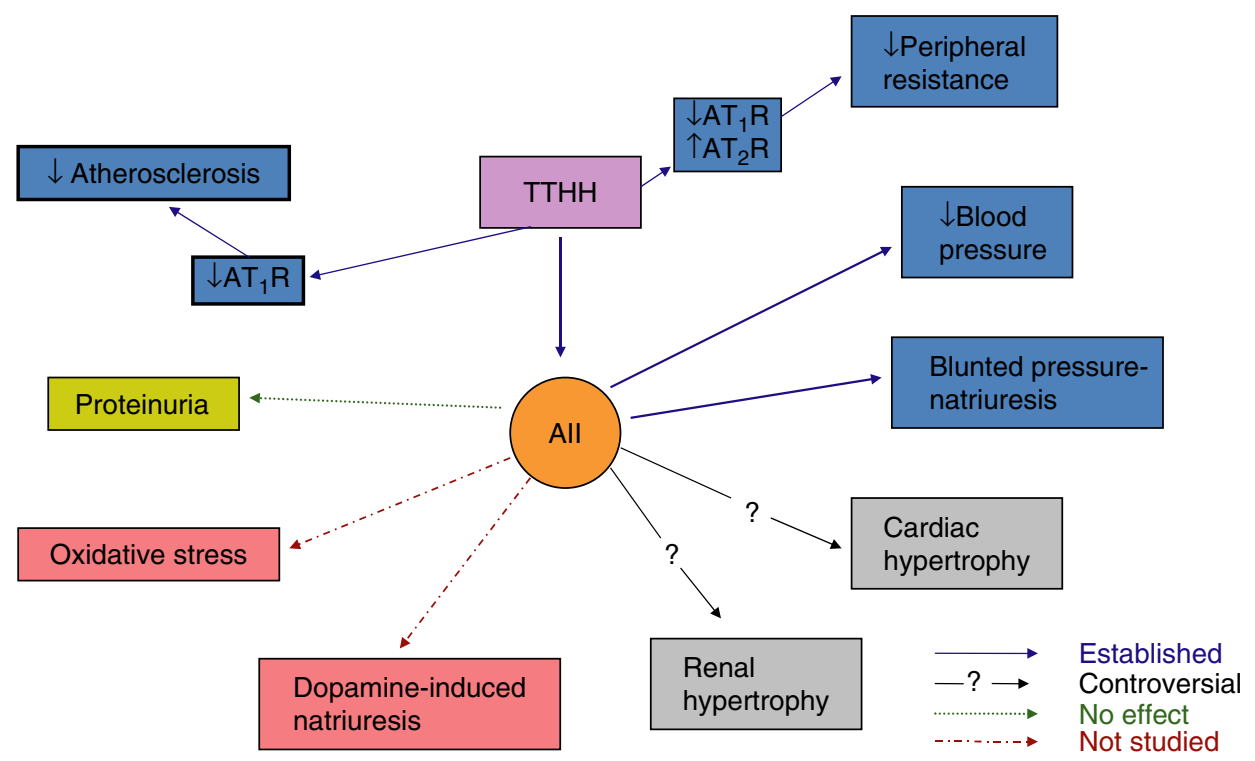

Figure 1 Role of thyroid hormones and the renin-angiotensin system in the cardiovascular and renal manifestations of thyroid hormone excess. The figure summarizes the confirmed and potential participation of All in the effects of thyroid hormones. TTHH, thyroid hormones; All, angiotensin II; $A T_{1} R$ and $A T_{2} R$, angiotensin type 1 and type 2 receptors. A full colour version of this figure is available via http://dx.doi.org/10.1530/JOE-11-0349.

(Rodríguez-Gómez et al. 2003) or BP, given that it is not reduced by antihypertensive therapy (Rodríguez-Gómez et al. 2003, Moreno et al. 2005). These observations suggest that proteinuria in the hyperthyroid state may be attributable to the direct action of thyroid hormones in increasing the permeability of the glomerular barrier. In this respect, Tanwani et al. (2002) also observed proteinuria in patients with Graves' disease.

Renal aminopeptidases regulate intrarenal RAS activity, modulating the degradation of RAS peptides (Segarra et al. 2006). Damaged tubular cells release these enzymes into the ultrafiltrate, thereby increasing their activity in urine. Our group recently investigated urinary aminopeptidase activities as early biomarkers of kidney injury, finding that a higher activity of urinary aminopeptidases precedes the increase in proteinuria in hyperthyroid rats (Perez-Abud et al. 2011). Moreover, from a diagnostic standpoint, urinary aminopeptidase values may be suitable predictors of renal injury.

\section{Perspectives}

This review discusses changes in the RAS induced by thyroid hormones and reports novel insights into the participation of the RAS in the main cardiovascular and renal manifestations of hyper- and hypothyroidism. It is known that the heart and blood vessels can intracellularly generate AII, but the effect of thyroid disorders on this process and its significance are poorly understood. Further research is also warranted on the relationship between the RAS and other important factors related to thyroid disorders (e.g. NO production, oxidative stress, and dopamine-induced natriuresis) and on the role of new RAS activation pathways in the regulation of cardiovascular and renal function and, therefore, in long-term BP control (Fig. 1).

\section{Declaration of interest}

The authors declare that there is no conflict of interest that could be perceived as prejudicing the impartiality of the research reported.

\section{Funding}

This study was supported by a grant (SAF2009-12294) from the Ministry of Education and Science and from the Carlos III Health Institute of the Spanish Ministry of Health and Consumer Affairs (Red de Investigación Renal, REDinREN RD06/0016/0017 and RD07/0016/2008). 'FEDER una manera de hacer Europa'.

\section{References}

Alfrey AC 1986 Thyroid and parathyroid hormones in experimental renal failure. In The Progressive Nature of Renal Disease, pp 37-44. Eds BM Brenner \& JH Stein. New York: Churchill Livingstone.

Andrade J, Haro JM, Jódar E, Luna JD \& Vargas F 1992 Effects of methimazole on low renal mass hypertension: changes on blood pressure and pressor responsiveness to vasoconstrictors. Pharmacology 44 315-323. (doi:10.1159/ 000138936)

Ashizawa K, Imaizumi M, Usa T, Tominaga T, Sera N, Hida A, Ejima E, Neriishi K, Soda M, Ichimaru S et al. 2010 Metabolic cardiovascular disease risk factors and their clustering in subclinical hypothyroidism. Clinical Endocrinology 72 689-695. (doi:10.1111/j.1365-2265.2009.03697.x) 
Atlas SA, Sealey JE, Larag JH \& Moon C 1977 Plasma renin and "prorenin" in essential hypertension during sodium depletion, beta-blockade and reduced arterial pressure. Lancet 2 785-789. (doi:10.1016/S0140-6736 (77) $90723-1)$

Bader M 2002 Role of the local renin-angiotensin system in cardiac damage: a minireview focussing on transgenic animal models. Journal of Molecular and Cellular Cardiology 34 1455-1462. (doi:10.1006/jmcc.2002.2077)

Baker KM \& Aceto JF 1990 Angiotensin II stimulation of protein synthesis and cell growth in chick heart cells. American Journal of Physiology 259 H610-H618.

Barreto-Chaves MLM, Carrillo-Sepúlveda MA, Carneiro-Ramos MS, Gomes DA \& Diniz GP 2010 The crosstalk between thyroid hormones and the renin-angiotensin system. Vascular Pharmacology 52 166-170. (doi:10. 1016/j.vph.2009.10.009)

Barth JD, Jansen H, Kromhout D, Reiber JH, Birkenhager JC \& Arntzenius AC 1987 Progression and regression of human coronary atherosclerosis: the role of lipoproteins, lipases and thyroid hormones in coronary lesion growth. Atherosclerosis 68 51-58. (doi:10.1016/0021-9150(87)90093-1)

Bedotto JB, Gay RG, Graham SD, Morkin E \& Goldman S 1989 Cardiac hypertrophy induced by thyroid hormone is independent of loading conditions and beta adrenoceptor blockade. Journal of Pharmacology and Experimental Therapeutics 248 632-636.

Boelen A, Platvoet-ter Schiphorst MC, Bakker O \& Wiersinga WM 1995 The role of cytokines in the lipopolysaccharide-induced sick euthyroid syndrome in mice. Journal of Endocrinology 146 475-483. (doi:10.1677/joe. $0.1460475)$

Booz GW 2004 Cardiac angiotensin $\mathrm{AT}_{2}$ receptor: what exactly does it do? Hypertension 43 1162-1163. (doi:10.1161/01.HYP.0000128531.39964.c0)

Bouhnik J, Galen FX, Clauser E, Menard J \& Corvol P 1981 The reninangiotensin system in thyroidectomized rats. Endocrinology 108 647-650. (doi:10.1210/endo-108-2-647)

Bradley SE, Stephan F, Coelho JB \& Reville P 1974 The thyroid and the kidney. Kidney International 6 346-365. (doi:10.1038/ki.1974.119)

Brent GA, Williams GR, Harney JW, Forman BM, Samuels HH, Moore DD \& Larsen PR 1991 Effects of varying the position of thyroid hormone response elements within the rat growth hormone promoter: implications for positive and negative regulation by 3,5,30-triiodothyronine. Molecular Endocrinology 5 542-548. (doi:10.1210/mend-5-4-542)

Cai Y, Ren Y \& Shi J 2011 Blood pressure levels in patients with subclinical thyroid dysfunction: a meta-analysis of cross-sectional data. Hypertension Research 34 1098-1105. (doi:10.1038/hr.2011.91)

Carlin K \& Carlin S 1993 Possible etiology for euthyroid sick syndrome. Medical Hypotheses 40 38-43. (doi:10.1016/0306-9877(93)90194-U)

Carneiro-Ramos MS, Silva VB, Santos RA \& Barreto-Chaves ML 2006 Tissue-specific modulation of angiotensin-converting enzyme (ACE) in hyperthyroidism. Peptides 11 2942-2949. (doi:10.1016/j.peptides.2006. 04.015)

Carneiro-Ramos MS, Diniz GP, Almeida J, Vieira RL, Pinheiro SV, Santos RA \& Barreto-Chaves ML 2007 Cardiac angiotensin II type I and type II receptors are increased in rats submitted to experimental hypothyroidism. Journal of Physiology 583 213-223. (doi:10.1113/jphysiol.2007.134080)

Carneiro-Ramos MS, Diniz GP, Nadu AP, Almeida J, Vieira RL, Santos RA \& Barreto-Chaves ML 2010 Blockage of angiotensin II type 2 receptor prevents thyroxine-mediated cardiac hypertrophy by blocking Akt activation. Basic Research in Cardiology 105 325-335. (doi:10.1007/s00395010-0089-0)

Casellas D, Bouriquet N \& Herizi A 1997 Bosentan prevents preglomerular alterations during angiotensin II hypertension. Hypertension 30 1613-1620. (doi:10.1161.HYP.30.6.1613)

Chan JSD, Ming M, Nie ZR, Silkstrom R, Lachance S \& Carrière S 1992 Hormonal regulation of expression of the angiotensinogen gene in cultured opossum kidney proximal tubular cells. Journal of the American Society of Nephrology 2 1516-1522.

Chen K, Carey LC, Valego NK, Liu JL \& Rose JC 2005 Thyroid hormone modulates renin and Ang II receptor expression in fetal sheep. American Journal of Physiology. Regulatory, Integrative and Comparative Physiology 289 R1006-R1014. (doi:10.1152/ajpregu.00046.2005)
Churchill PC, Churchill MC \& McDonald FD 1983 Evidence that beta 1-adrenoceptor activation mediates isoproterenol-stimulated renin secretion in the rat. Endocrinology 113 687-692. (doi:10.1210/endo113-2-687)

Clauser E, Bouhnik J, Coezy E, Corvol P \& Menard J 1983 Synthesis and release of immunoreactive angiotensiogen by rat liver slices. Endocrinology 112 1188-1193. (doi:10.1210/endo-112-4-1188)

Conger JD, Falk SA \& Gillum DM 1989 The protective mechanism of thyroidectomy in a rat model of chronic renal failure. American Journal of Kidney Diseases 13 217-225.

Cruz A, Rodríguez-Gómez I, Pérez-Abud R, Vargas MÁ, Wangensteen R, Quesada A, Osuna A \& Moreno JM 2011 Effects of clofibrate on salt loading-induced hypertension in rats. Journal of Biomedicine \& Biotechnology 2011 469481. (doi:10.1155/2011/469481)

Dasarathy Y, Stevens J, Lanzillo JJ \& Fanburg BL 1990 Elevation of angiotensin converting enzyme in bovine endothelial cells quantitated by an ELISA. Life Sciences 47 883-889. (doi:10.1016/0024-3205(90)90602-N)

Davis PJ, Davis FB \& Cody V 2005 Membrane receptors mediating thyroid hormone action. Trends in Endocrinology and Metabolism 16 429-435. (doi:10.1016/j.tem.2005.09.007)

Diniz GP, Carneiro-Ramos MS \& Barreto-Chaves ML 2007 Angiotensin type $1\left(\mathrm{AT}_{1}\right)$ and type $2\left(\mathrm{AT}_{2}\right)$ receptors mediate the increase in TGF-beta1 in thyroid hormone-induced cardiac hypertrophy. Pflügers Archiv 454 75-81. (doi:10.1007/s00424-006-0192-0)

Diniz GP, Carneiro-Ramos MS \& Barreto-Chaves ML 2009 Angiotensin type 1 receptor mediates thyroid hormone-induced cardiomyocyte hypertrophy through the AKT/GSK-3 $\beta / \mathrm{mTOR}$ signaling pathway. Basic Research in Cardiology 104 653-667. (doi:10.1007/s00395-009-0043-1)

Donangelo I \& Braunstein GD 2011 Update on subclinical hyperthyroidism. American Family Physician 83 933-938.

Dostal DE, Rothblum KN, Conrad KM, Cooper GR \& Baker KM 1992 Detection of angiotensin I and II in cultured rat cardiac myocytes and fibroblasts. American Journal of Physiology 263 C851-C863.

Duggal J, Singh S, Barsano CP \& Arora R 2007 Cardiovascular risk with subclinical hyperthyroidism and hypothyroidism: pathophysiology and management. Journal of the Cardiometabolic Syndrome 2 198-206. (doi:10.1111/j.1559-4564.2007.06583.x)

Dunn FG, Oigman W, Ventura HO, Messerli FH, Kobrin I \& Frohlich ED 1984 Enalapril improves systemic and renal hemodynamics and allows regression of left ventricular mass in essential hypertension. American Journal of Cardiology 53 105-108. (doi:10.1016/0002-9149 (84)90692-1)

Dzau VJ \& Herrmann HC 1982 Hormonal control of angiotensinogen production. Life Sciences 30 577-584. (doi:10.1016/0024-3205(82) 90272-7)

Economidou F, Douka E, Tzanela M, Nanas S \& Kotanidou A 2011 Thyroid function during critical illness. Hormones 10 117-124.

Emdin M, Passino C, Prontera C, Iervasi A, Ripoli A, Masini S, Zucchelli GC \& Clerico A 2004 Cardiac natriuretic hormones, neuro-hormones, thyroid hormones and cytokines in normal subjects and patients with heart failure. Clinical Chemistry and Laboratory Medicine 42 627-636. (doi:10.1515/ CCLM.2004.108)

Eppenberger-Eberhardt M, Aigner S, Donath MY, Kurer V, Walther P, Zuppinger C, Schaub MC \& Eppenberger HM 1997 IGF-I and bFGF differentially influence atrial natriuretic factor and alpha-smooth muscle actin expression in cultured atrial compared to ventricular adult rat cardiomyocytes. Journal of Molecular and Cellular Cardiology 29 2027-2039. (doi:10.1006/jmcc.1997.0408)

Fischer P \& Hilfiker-Kleiner D 2007 Survival pathways in hypertrophy and heart failure: the gp130-STAT3 axis. Basic Research in Cardiology 102 279-297. (doi:10.1007/s00395-007-0658-z)

Folkow B 1990 Structural factor in primary and secondary hypertension. Hypertension 16 89-101.

Fontana M, Passino C, Poletti R, Zyw L, Prontera C, Scarlattini M, Clerico A, Emdin M \& Iervasi G 2012 Low triiodothyronine and exercise capacity in heart failure. International Journal of Cardiology 154 153-157. (doi:10.1016/ j.ijcard.2010.09.002) 
Fukuyama K, Ichiki T, Takeda K, Tokunou T, Iino N, Masuda S, Ishibashi M, Egashira K, Shimokawa H, Hirano K et al. 2003 Downregulation of vascular angiotensin II type 1 receptor by thyroid hormone. Hypertension 41 598-603. (doi:10.1161/01.HYP.0000056524.35294.80)

Furchgott RF \& Vanhoutte PM 1989 Endothelium-derived relaxing and contracting factors. FASEB Journal 3 2007-2018.

Fyhrquist F \& Saijonmaa O 2008 Renin-angiotensin system revisited. Journal of Internal Medicine 264 224-236. (doi:10.1111/j.1365-2796.2008. 01981.x)

Ganong WF 1982 Thyroid hormones and renin secretion. Life Sciences 30 577-584. (doi:10.1016/0024-3205(82)90270-3)

García del Río C, Moreno MR, Osuna A, Luna JD, García-Estañ J \& Vargas F 1997 Role of the renin-angiotensin system in the development of thyroxine-induced hypertension. European Journal of Endocrinology 136 656-660. (doi:10.1530/eje.0.1360656)

García-Estañ J, Atucha N, Quesada T \& Vargas F 1995 Involvement of the renin-angiotensin in the reduced pressure-natriuresis response of hyperthyroid rats. American Journal of Physiology 268 E897-E901.

Gilbert MT, Sun J, Yan Y, Oddoux C, Lazarus A, Tansey WP, Lavin TN \& Catanzaro DF 1994 Renin gene promoter activity in GC is regulated by cAMP and thyroid hormone through Pit-1-dependent mechanisms. Journal of Biological Chemistry 269 28049-28054.

Gill GN, Ill CR \& Simonian MH 1977 Angiotensin stimulation of bovine adrenocortical cell growth. PNAS 74 5569-5573. (doi:10.1073/pnas.74. 12.5569)

Gottardis M, Koller J, Benzer A, Wieser C, Hackl JM, Koenigsrainer A, Herold M \& Fridrich L 1992 Atrial natriuretic peptide (ANP), aldosterone, angiotensin II and renin in the 'low $\mathrm{T}_{3}$ syndrome' in organ donors. Infusionstherapie und Transfusionsmedizin 19 181-182. 185-186.

Guyton AC 1980 Arterial Pressure and Hypertension, p 564. Philadelphia: Saunders.

Haro JM, Sabio JM \& Vargas F 1992 Renal and cardiac beta-adrenoceptors in thyroxine treated rats. Journal of Endocrinological Investigation 15 605-608.

Hauger-Klevene JH \& Levin GM 1976 Kinetics of renin system in hyper- and hypothyroidism. Medicina 36 219-222.

Hauger-Klevene JH, De Vito E \& Fasciolo JC 1977 The effect of thyroid hormone and renin production and release by rat kidney slices. Acta Physiologica Latino Americana 27 37-43.

Hekmat R, Javadi Z, Layghian Javan M, Sanadgol H, Gholami F, Mohebbi M, Zeraati AA, Ahmadnia H, Tabarraiei H, Baradaran M et al. 2010 Thyroid hormone changes in early kidney transplantation and its correlation with delayed graft function. Urology Journal 7 30-34.

Hermus RM, Sweep CG, Van der Meer MJ, Ross HA, Smals AG, Benraad TJ \& Kloppenborg PW 1992 Continuous infusion of interleukin-1 beta induces a nonthyroidal illness syndrome in the rat. Endocrinology 131 2139-2146. (doi:10.1210/en.131.5.2139)

Hong-Brown LQ \& Deschepper CF 1992 Effects of thyroid hormones on angiotensinogen gene expression in rat liver, brain and cultured cells. Endocrinology 130 1231-1237. (doi:10.1210/en.130.3.1231)

Hu LW, Benvenuti LA, Liberti EA, Carneiro-Ramos MS \& Barreto-Chaves ML 2003 Thyroxine-induced cardiac hypertrophy: influence of adrenergic nervous system versus renin-angiotensin system on myocyte remodeling. American Journal of Physiology. Regulatory, Integrative and Comparative Physiology 285 R1473-R1480.

Ichihara A, Kobori H, Miyashita Y, Hayashi M \& Saruta T 1998 Differential effects of thyroid hormone on renin secretion, content, and mRNA in juxtaglomerular cells. American Journal of Physiology 274 E224-E231.

Ichihara S, Senbonmatsu T, Price E Jr, Ichiki T, Gaffney FA \& Inagami T 2001 Angiotensin II type 2 receptor is essential for left ventricular hypertrophy and cardiac fibrosis in chronic angiotensin II-induced hypertension. Circulation 104 346-351.

Ichiki T 2010 Thyroid hormone and atherosclerosis. Vascular Pharmacology 52 151-156. (doi:10.1016/j.vph.2009.09.004)

Iervasi G, Pingitore A, Landi A, Raciti M, Ripoli A, Scarlattini M, L'Abbate A \& Donato L 2003 Low- $\mathrm{T}_{3}$ syndrome a strong prognostic predictor of death in patients with heart disease. Circulation 107 708-713. (doi:10.1161/01. CIR.0000048124.64204.3F)
Ignarro LJ, Lippton H, Edwards JC, Baricos WH, Hyman AL, Kadowitz PJ \& Gruetter CA 1981 Mechanism of vascular smooth muscle relaxation by organic nitrates, nitrites, nitroprusside, and nitric oxide: evidence for the involvement of nitrosothiols as active intermediates. Journal of Pharmacology and Experimental Therapeutics 218 739-749.

Jiménez E, Montiel M, Narváez JA \& Morell M 1982 Effects of hyper and hypothyroidism on the basal levels of angiotensin I and kinetic parameters of renin angiotensin system in male rats. Revista Española de Fisiología 38 149-154.

Jiménez E, Montiel M, Narváez JA \& Morell M 1984 Renin-angiotensin system in hypothyroid rats: effects of potassium iodide and triiodo-Lthyronine. Acta Endocrinologica 105 505-510.

Jiménez E, Ruiz M \& Montiel M 1990 Neonatal development of the angiotensin converting enzyme: effect of hypothyroidism. In Endocrine and Biochemical Development of the Fetus and Neonate, Ed. JM Cuezva. New York: Plenum.

Katz AM 2003 Pathophysiology of heart failure: identifying targets for pharmacotherapy. Medical Clinics of North America 87 303-316. (doi:10.1016/S0025-7125(02)00188-8)

Kenessey A \& Ojamaa K 2006 Thyroid hormone stimulates protein synthesis in the cardiomyocyte by activating the Akt-mTOR and p70S6K pathways. Journal of Biological Chemistry 281 20666-20672. (doi:10.1074/jbc. M512671200)

Klein I 1988 Thyroxine-induced cardiac hypertrophy: time course of development and inhibition by propranolol. Endocrinology 123 203-210. (doi:10.1210/endo-123-1-203)

Klein I 1990 Thyroid hormone and the cardiovascular system. American Journal of Medicine 88 631-637. (doi:10.1016/0002-9343(90)90531-H)

Klein I 2003 Thyroid hormone and cardiac contractility. American Journal of Cardiology 91 1331-1332. (doi:10.1016/S0002-9149(03)00433-8)

Klein I \& Ojamaa K 1995 Thyroid hormone and blood pressure regulation. In Hypertension: Pathophysiology, Diagnosis and Management, Eds JH Laragh \& BN Brenner. New York: Raven Press Ltd.

Klein I \& Ojamaa K 2001 Thyroid hormone and the cardiovascular system. New England Journal of Medicine 344 501-509. (doi:10.1056/ NEJM200105103441901)

Kobori H, Ichihara A, Suzuki H, Takenaka T, Miyashita Y, Hayashi M \& Saruta T 1997a Role of the renin-angiotensin system in cardiac hypertrophy induced in rats by hyperthyroidism. American Journal of Physiology 273 H593-H599.

Kobori H, Ichihara A, Suzuki H, Miyashita Y, Hayashi M \& Saruta T 1997 b Thyroid hormone stimulates renin synthesis in rats without involving the sympathetic nervous system. American Journal of Physiology 272 E227-E232.

Kobori H, Ichihara A, Miyashita Y, Hayashi M \& Saruta T 1998 Mechanism of hyperthyroidism-induced renal hypertrophy in rats. Journal of Endocrinology 159 9-14. (doi:10.1677/joe.0.1590009)

Kobori H, Ichihara A, Miyashita Y, Hayashi M \& Saruta T 1999 Local renin-angiotensin system contributes to hyperthyroidism-induced cardiac hypertrophy. Journal of Endocrinology 160 43-47. (doi:10.1677/joe.0. 1600043)

Kobori H, Hayashi M \& Saruta T 2001 Thyroid hormone stimulates renin gene expression through the thyroid hormone response element. Hypertension 37 99-104.

Koehn MA, Schindler WJ \& Stanton HC 1967 Thyroid state and vascular reactivity in rats. Proceedings of the Society for Experimental Biology and Medicine 126 861-864.

Kozdag G, Ural D, Vural A, Agacdiken A, Kahraman G, Sahin T, Ural E \& Komsuoglu B 2005 Relation between free triiodothyronine/free thyroxine ratio, echocardiographic parameters and mortality in dilated cardiomyopathy. European Journal of Heart Failure 7 113-118. (doi:10.1016/j. ejheart.2004.04.016)

Kumar R, Singh VP \& Baker KM 2007 The intracellular renin-angiotensin system: a new paradigm. Trends in Endocrinology and Metabolism 18 208-214. (doi:10.1016/j.tem.2007.05.001)

Kumar R, Singh VP \& Baker KM 2008 The intracellular renin-angiotensin system: implications in cardiovascular remodeling. Current Opinion in Nephrology and Hypertension 17 168-173. (doi:10.1097/MNH. Ob013e3282f521a8) 
Kurtz A 2011 Renin release: sites, mechanisms and control. Annual Review of Physiology 73 377-399. (doi:10.1146/annurev-physiol-012110-142238)

Kuzman JA, Vogelsang KA, Thomas TA \& Gerdes AM 2005 L-thyroxine activates Akt signaling in the heart. Journal of Molecular and Cellular Cardiology 39 251-258. (doi:10.1016/j.yjmcc.2005.03.020)

Larsen PR, Davis TF \& Hay ID 1998 The thyroid gland. In Williams Textbook of Endocrinology, Eds JD Wilson, DW Foster, HK Kronenberg \& PR Larsen. London: WB Saunders \& Company.

Lev-Ran A 1994 Thyroid hormones and prevention of atherosclerotic heart disease: an old-new hypothesis. Perspectives in Biology and Medicine 37 486-494.

Lim VS, Henriquez C, Seo H, Refetoff S \& Martino E 1980 Thyroid function in a uremic rat model. Evidence suggesting tissue hypothyroidism. Journal of Clinical Investigation 66 946-954. (doi:10.1172/JCI109963)

Lonn E, Yusuf S, Dzavik V, Doris C, Yi Q, Smith S, Moore-Cox A, Bosch J, Riley W, Teo K et al. 2001 Effects of ramipril and vitamin $\mathrm{E}$ on atherosclerosis: the study to evaluate carotid ultrasound changes in patients treated with ramipril and vitamin E (SECURE). Circulation 103 919-925.

Marchant C, Brown L \& Sernia C 1993 Renin-angiotensin system in thyroid dysfunction in rats. Journal of Cardiovascular Pharmacology 22 449-455. (doi:10.1097/00005344-199309000-00016)

McLeod JD \& Piper PJ 1992 Effects of $\mathrm{K}^{+}$channel-modulating drugs on the vasoconstrictor responses of leukotrienes C4, D4 and angiotensin II in the guinea-pig isolated perfused heart. British Journal of Pharmacology $105739-743$.

Mebis L \& Van den Berghe G 2011 Thyroid axis function and dysfunction in critical illness. Best Practice \& Research. Clinical Endocrinology \& Metabolism 25 745-757. (doi:10.1016/j.beem.2011.03.002)

Michel B, Grima M, Coquard C, Welsch C, Barthelmebs M \& Imbs JL 1994 Effects of triiodothyronine and dexamethasone on plasma and tissue angiotensin converting enzyme in the rat. Fundamental \& Clinical Pharmacology 8 366-372. (doi:10.1111/j.1472-8206.1994.tb00814.x)

Mifune M, Sasamura H, Shimizu-Hirota R, Miyazaki H \& Saruta T 2000 Angiotensin II type 2 receptors stimulate collagen synthesis in cultured vascular smooth muscle cells. Hypertension 36 845-850.

Mikhail GS, Alshammari SM, Alenezi MY, Mansour M \& Khalil NA 2008 Increased atherogenic low-density lipoprotein cholesterol in untreated subclinical hypothyroidism. Endocrine Practice 14 570-575.

Millat LJ, Abdel-Rahman EM \& Siragy HM 1999 Angiotensin II and nitric oxide: a question of balance. Regulatory Peptides 81 1-10. (doi:10.1016/ S0167-0115(99)00027-0)

Montiel M, Ruiz M, Jiménez E \& Morell M 1987 Angiotensin converting enzyme in hyper- and hypothyroid rats. Hormone and Metabolic Research 19 90-92. (doi:10.1055/s-2007-1011749)

Moreno JM, Wangensteen R, Sainz J, Rodriguez-Gomez I, Chamorro V, Osuna A \& Vargas F 2003 Role of endothelium-derived relaxing factors in the renal response to vasoactive agents in hypothyroid rats. American Journal of Physiology. Endocrinology and Metabolism 285 E182-E189.

Moreno JM, Rodríguez-Gómez I, Wangensteen R, Osuna A, Bueno P \& Vargas F 2005 Cardiac and renal antioxidant enzymes and effects of tempol in hyperthyroid rats. American Journal of Physiology. Endocrinology and Metabolism 289 E776-E783. (doi:10.1152/ajpendo.00611.2004)

Morgan HE \& Baker KM 1991 Cardiac hypertrophy. Mechanical, neural, and endocrine dependence. Circulation 83 13-25.

Ochs N, Auer R, Bauer DC, Nanchen D, Gussekloo J, Cornuz J \& Rodondi N 2008 Meta-analysis: subclinical thyroid dysfunction and the risk for coronary heart disease and mortality. Annals of Internal Medicine 148 832-845.

Perez-Abud R, Rodríguez-Gómez I, Villarejo AB, Moreno JM, Wangensteen R, Tassi M, O'Valle F, Osuna A \& Vargas F 2011 Salt sensitivity in experimental thyroid disorders in rats. American Journal of Physiology. Endocrinology and Metabolism 301 E281-E287. (doi:10.1152/ajpendo.00690.2010)

Peti-Peterdi J 2010 High glucose and renin release: the role of succinate and GPR91. Kidney International 78 1214-1217. (doi:10.1038/ki.2010.333)

Phillips MI, Speakman EA \& Kimura B 1993 Levels of angiotensin and molecular biology of the tissue renin angiotensin systems. Regulatory Peptides 43 1-20. (doi:10.1016/0167-0115(93)90403-U)
Pingitore A, Landi P, Taddei MC, Ripoli A, L’Abbate A \& Iervasi G 2005 Triiodothyronine levels for risk stratification of patients with chronic heart failure. American Journal of Medicine 118 132-136. (doi:10.1016/j.amjmed. 2004.07.052)

Pingitore A, Galli E, Barison A, Iervasi A, Scarlattini M, Nucci D, L'Abbate A, Mariotti R \& Iervasi G 2008 Acute effects of triiodothyronine $\left(T_{3}\right)$ replacement therapy in patients with chronic heart failure and low- $\mathrm{T}_{3}$ syndrome: a randomized, placebo-controlled study. Journal of Clinical Endocrinology and Metabolism 93 1351-1358. (doi:10. 1210/jc.2007-2210)

Prieto-Carrasqueo MC, Botros FT, Kobori H \& Navar LG 2009 Collecting duct renin: a major player in angiotensin II-dependent hypertension. Journal of the American Society of Hypertension 3 96-104. (doi:10.1016/j.jash. 2008.11.003)

Razvi S, Weaver JU, Vanderpump MP \& Pearce SH 2010 The incidence of ischemic heart disease and mortality in people with subclinical hypothyroidism: reanalysis of the Whickham Survey cohort. Journal of Clinical Endocrinology and Metabolism 95 1734-1740. (doi:10.1210/jc. 2009-1749)

Reiners C, Gramer-Kurz E, Pickert E \& Schweisfurth H 1988 Changes of serum angiotensin-I-converting enzyme in patients with thyroid disorders. Clinical Physiology and Biochemistry 6 44-49.

Rodríguez-Gómez I, Sainz J, Wangensteen R, Moreno JM, Duarte J, Osuna A \& Vargas F 2003 Increased pressor ensitivity to chronic nitric oxide deficiency in hyperthyroid rats. Hypertension 42 220-225. (doi:10.1161/01.HYP.0000081944.47230.69)

Romaldini JH, Sgarbi JA \& Farah CS 2004 Subclinical thyroid disease: subclinical hypothyroidism and hyperthyroidism. Arquivos Brasileiros de Endocrinologia e Metabologia 48 147-158. (doi:10.1590/S000427302004000100016)

Ruiz M, Montiel M, Jiménez E \& Morell M 1987 Effect of thyroid hormones on angiotensinogen production in rat in vivo and in vitro. Journal of Endocrinology 115 311-315. (doi:10.1677/joe.0.1150311)

Sabineau JP \& Marthan R 1993 Effect of cromakalim on KCl-, noradrenaline- and angiotensin II-induced contractions in the rat pulmonary artery. Pulmonary Pharmacology 6 41-48. (doi:10.1006/pulp. 1993.1007)

Sabio JM, Rodríguez-Maresca M, Luna JD, García del Rio C \& Vargas F 1994 Vascular reactivity to vasoconstrictors in aorta and renal vasculature from hyperthyroid and hypothyroid rats. Pharmacology 49 257-264. (doi:10. $1159 / 000139241)$

Sadoshima J \& Izumo S 1993 Molecular characterization of angiotensin II-induced hypertrophy of cardiac myocytes and hyperplasia of cardiac fibroblasts. Critical role of the $\mathrm{AT}_{1}$ receptor subtype. Circulation Research 73 413-423.

Sahún M, Villabona C, Rosel P, Navarro MA, Ramón JM, Gómez JM \& Soler J 2001 Water metabolism disturbances at different stages of primary thyroid failure. Journal of Endocrinology 168 435-445. (doi:10.1677/joe.0. 1680435)

Santos RA \& Ferreira AJ 2007 Angiotensin-(1-7) and the renin-angiotensin system. Current Opinion in Nephrology and Hypertension 16 122-128. (doi:10. 1097/MNH.0b013e328031f362)

Segarra AB, Ramírez M, Banegas I, Hermoso F, Vargas F, Vives F, Alba F, de Gasparo M \& Prieto I 2006 Influence of thyroid disorders on kidney angiotensinase activity. Hormone and Metabolic Research 38 48-52. (doi:10. 1055/s-2006-924978)

Sernia C, Marchant C, Brown L \& Hoey A 1993 Cardiac angiotensin receptors in experimental hyperthyroidism in dogs. Cardiovascular Research 27 423-428. (doi:10.1093/cvr/27.3.423)

Stephan F, Reville P, de Laharpe F \& Köll-Back MH 1982 Impairment of renal compensatory hypertrophy by hypothyroidism in the rat. Life Sciences 30 623-631. (doi:10.1016/0024-3205(82)90278-8)

Strawn WB, Chappell MC, Dean RH, Kivlighn S \& Ferrario CM 2000 Inhibition of early atherogenesis by losartan in monkeys with diet-induced hypercholesterolemia. Circulation 101 1586-1593.

Tanwani LK, Lohano V, Broadstone VL \& Mokshagundam SP 2002 Minimal change nephropathy and Graves' disease: report of a case and review of the literature. Endocrine Practice 8 40-43. 
Tognini S, Marchini F, Dardano A, Polini A, Ferdeghini M, Castiglioni M \& Monzani F 2010 Non-thyroidal illness syndrome and short-term survival in a hospitalised older population. Age and Ageing 39 46-50. (doi:10.1093/ ageing/afp197)

Urata H, Kinoshita A, Misono KS, Bumpus FM \& Husain A 1990 Identification of a highly specific chymase as the major angiotensin II-forming enzyme in the human heart. Journal of Biological Chemistry 265 22348-22357.

Van Lente F \& Daher R 1992 Plasma selenium concentrations in patients with euthyroid sick syndrome. Clinical Chemistry 38 1885-1888.

Vargas F, García del Rio C, Luna JD, Haro JM \& Osorio C 1988 Studies on thyroid activity in deoxycorticosterone-salt and Goldblatt two-kidney, one-clip hypertensive rats. Acta Endocrinologica 118 22-30.

Vargas F, Baz MJ, Andrade J, Luna JD \& Haro JM 1991 Thyroid state and pressor responsiveness to vasoconstrictors in conscious rats. Medical Science Research 19 239-241.

Vargas F, Castillo MA \& Haro JM 1992 Methimazole treatment reduces cardiac hypertrophy and mortality without a concomitant reduction in blood pressure in established Goldblatt two-kidney one clip hypertension. Experientia 48 755-758. (doi:10.1007/BF02124296)

Vargas F, Atucha N, Sabio JM, Quesada T \& García-Estañ J 1994 Pressure diuresis-natriuresis response in hyperthyroid and hypothyroid rats. Clinical Science 87 323-328.

Vargas F, Fernández-Rívas A, García-Estañ J \& Garcia del Rio C 1995 Endothelium-dependent and endothelium-independent vasodilation in hyperthyroid and hypothyroid rats. Pharmacology 51 308-314. (doi:10. 1159/000139340)

Vargas F, Moreno JM, Rodríguez-Gómez I, Wangensteen R, Osuna A, Alvarez-Guerra M \& García-Estañ J 2006 Vascular and renal function in experimental thyroid disorders. European Journal of Endocrinology 154 197-212. (doi:10.1530/eje.1.02093)
Vargas SL, Toma I, Kang JJ, Meer EJ \& Peti-Peterdi J 2009 Activation of the succinate receptor GPR91 in macula densa cells causes renin release. Journal of the American Society of Nephrology 20 1002-1011. (doi:10.1681/ASN. 2008070740)

Wada H, Zile MR, Ivester CT, Cooper G IV \& McDermott PJ 1996 Comparative effects of contraction and angiotensin II on growth of adult feline cardiocytes in primary culture. American Journal of Physiology 271 H29-H37.

Warner MH \& Beckett GJ 2010 Mechanisms behind the non-thyroidal illness syndrome: an update. Journal of Endocrinology 205 1-13. (doi:10.1677/JOE09-0412)

Weetman AP, Tomlinson K, Amos N, Lazarus JH, Hall R \& McGregor AM 1985 Proteinuria in autoimmune thyroid disease. Acta Endocrinologica $109341-347$.

Williams GR, Franklyn JA, Neuberger JM \& Sheppard MC 1989 Thyroid hormone receptor expression in the "sick euthyroid" syndrome. Lancet 2 1477-1478. (doi:10.1016/S0140-6736(89)92930-9)

Zoccali C, Tripepi G, Cutrupi S, Pizzini P \& Mallamaci F 2005 Low triiodothyronine: a new facet of inflammation in end-stage renal disease. Journal of the American Society of Nephrology 16 2789-2795. (doi:10.1681/ ASN.2005040356)

\section{Received in final form 28 October 2011 \\ Accepted 31 October 2011 \\ Made available online as an Accepted Preprint 31 October 2011}

